\title{
The analysis of spark ignition engine short-time supercharging
}

\author{
The paper presents the analysis of improvement of spark ignition engine operation indexes by means of short-time \\ supercharging. The simulation and engine test stand investigation results of the air flow in the spark ignition combustion \\ engine intake system have been shown here.
}

Key words: accelerability, combustion engine, simulation tests, air flow, intake manifold, short-time supercharging

\section{Analiza krótkotrwałego doładowania silnika o zapłonie iskrowym}

\begin{abstract}
W artykule przeanalizowano możliwości poprawy wskaźników pracy silnika o zapłonie iskrowym przez zastosowanie krótkotrwałego doładowania. Przedstawiono wyniki badań symulacyjnych i stanowiskowych przepływu powietrza w układzie dolotowym silnika spalinowego o zapłonie iskrowym.

Słowa kluczowe: zdolność przyspieszania, silnik spalinowy, badania symulacyjne, przepływ powietrza, kolektor dolotowy, doładowanie krótkookresowe
\end{abstract}

\section{Introduction}

The reduction of toxic emissions is the main direction of tests carried out on combustion engines [3, 10, 17, 18]. We should not forget, however, of the basic function of the engine, namely the generation of mechanical power $[5,11$, $13,15,21]$. The use of a combustion engine as the source of propulsion often means a necessity of quick changes of the generated power, frequently to a significant extent $[7-10$, $12,14,16,20]$. Engine power $\left(\mathrm{N}_{\mathrm{e}}\right)$ is the product of torque $\left(\mathrm{M}_{\mathrm{o}}\right)$ and crankshaft angular velocity $\left(\omega_{\mathrm{s}}\right)$

$$
\mathrm{N}_{\mathrm{e}}=\mathrm{M}_{\mathrm{o}} \cdot \omega_{\mathrm{s}}
$$

Thus, the engine power increase is determined by the dependency:

$$
\Delta \mathrm{N}_{\mathrm{e}}=\Delta \mathrm{M}_{\mathrm{o}} \cdot \omega_{\mathrm{s}}+\mathrm{M}_{\mathrm{o}} \cdot \Delta \omega_{\mathrm{s}}+\Delta \mathrm{M}_{\mathrm{o}} \cdot \Delta \omega_{\mathrm{s}}
$$

In order to increase the engine power, it is necessary to increase its torque or crankshaft angular velocity. Under quasi-stationary operating conditions, the engine inertia and its systems can be neglected. In the dynamic state, the delay of a response to a change in the control signal, and, most of all, the mechanical inertia resulting from the heavy weight of the moving engine parts, must be taken into account. The issue analyzed in this paper gains particular importance in drive systems enabling a transfer of power with a variable value of the drivetrain kinematic ratio. The control strategy directed to a reduction of the fuel consumption $\left(\mathrm{CO}_{2}\right.$ emission) is related to the engine operation at low crankshaft velocity and high torque at a specified vehicle speed. As a result, the torque reserve (measured from the $\mathrm{M}_{\mathrm{zw}}$ external characteristics) is low, which, according to the equation

$$
\left(M_{z w}-M_{o}\right)=J_{s} \cdot \frac{d \omega_{s}}{d t}
$$

\section{Wprowadzenie}

Zmniejszenie emisji substancji szkodliwych to główne kierunki prowadzonych badań nad silnikami spalinowymi $[3,10,17,18]$. Nie można jednak zapomnieć o podstawowej funkcji silnika, która polega na generowaniu mocy mechanicznej $[5,11,13,15,21]$. Wykorzystanie silnika spalinowego $\mathrm{w}$ charakterze jednostki napędowej wiąże się z koniecznością szybkiej zamiany generowanej mocy, często w znacznym zakresie [7-10, 12, 14, 16, 20]. Moc silnika $\left(\mathrm{N}_{\mathrm{e}}\right)$ jest iloczynem jego momentu obrotowego $\left(\mathrm{M}_{\mathrm{o}}\right)$ i prędkości kątowej wału korbowego $\left(\omega_{\mathrm{s}}\right)$ - równanie (1). Zatem przyrost mocy silnika określa zależność (2).

Dla zwiększenia mocy silnika konieczne jest zwiększenie jego momentu obrotowego względnie prędkości kątowej wału korbowego. W quasi-stacjonarnych warunkach pracy pominąć można bezwładność silnika i jego układów. W stanie dynamicznym uwzględnić należy opóźnienie w odpowiedzi na zmianę sygnału sterowania, a przede wszystkim bezwładność mechaniczną wynikającą z dużej masy elementów ruchomych silnika. Rozpatrywany w opracowaniu problem nabiera szczególnego znaczenia $\mathrm{W}$ układach napędowych umożliwiających przenoszenie mocy przy zmiennej wartości przełożenia kinematycznego układu przeniesienia napędu. Strategia sterowania zorientowana na ograniczenie zużycia paliwa (emisja $\mathrm{CO}_{2}$ ) wiąże się z pracą silnika przy małej prędkości wału korbowego i dużym momencie obrotowym, przy określonej prędkości ruchu samochodu. W rezultacie zapas momentu obrotowego (mierzonego od charakterystyki zewnętrznej $\mathrm{M}_{z \mathrm{w}}$ ) jest mały, co zgodnie z równaniem (3) ogranicza możliwość uzyskania znacznego przyspieszenia wału korbowego, a tym samym uzyskanie istotnego przyrostu mocy silnika w krótkim czasie. W celu poprawy dynamiki układu napędowego w artykule szczegółowej analizie poddano koncepcję zasobnikowego doładowania silnika. 
restricts the possibility of obtaining significant crankshaft acceleration and thus, obtainment of significant engine power in a short time. To improve the drive system dynamics, the paper included a detailed analysis of accumulative supercharging.

\section{The spark ignition engine short-term super- charging system}

The application of supercharging is one of the ways of increasing the engine torque. The references $[4,14,15,18$, $19,22]$ present numerous systems of continuous (e.g. compressor systems) or intermittent supercharging systems.

An interesting solution is the system presented in paper [19], consisting of a turbocharger and compressed air accumulator. At the moment of acceleration, when the turbocharger speed is insufficient, additional air from the accumulator is taken through a special system adjusting the air inflow into the cylinder. Thus, the air deficiency in the engine cylinder is refilled, which in consequence gives a higher torque and exhaust energy, achieving higher turbocharger acceleration. The maximum turbocharger efficiency was reached in this case by $3.5 \mathrm{~s}$ earlier as compared to the traditional system. The faster growth of the turbocharger speed also has a beneficial effect on the torque.

In the case of spark ignition, the issue is more complex, because of the risk of a knocking combustion with much charge in the cylinder. This unfavorable phenomenon can be restricted by lowering the charge temperature as a result of abrupt accumulative air decompression. Paper [14] presents the concept of such short-term supercharging system including determination of its basic parameters.

\section{Simulative tests on the phenomena in the intake manifold}

In order to examine the phenomena occurring in the intake system, its model was developed in the FLUENT package, serving to simulate the physical phenomena and flow analysis. The calculations made by means of this package are based on the finite volume method $[1-3,6]$. The calculative area was discretized and its boundary conditions defined. Subsequently, the steady and the dynamic states of the medium in the engine intake system - were tested.

The air flow simulations in the intake manifold for throttle angles were carried out at a steady engine speed. The flow phenomena at a rapid engine load increase, i.e. at steady engine speed and variable throttle angle were examined and the functioning of the short-time supercharging in the intake manifold were simulated $[12,14,16]$. Analyzing the simulation results, the air stream velocity distributions and pressures occurring in the intake manifold were determined and the data obtained were compared to the experimental values. Paper [6] presents the description of the mathematical model applied and the results for selected operating states are presented below.

The steady (quasi-static) flow was simulated at the engine speed of $\mathrm{n}=1800 \mathrm{rpm}$ and a constant throttle angle, then the next throttling valve opening angle was set, obtaining distributions of air flow directions and velocities.

\section{Układ krótkotrwałego doładowania silnika ZI}

Zastosowanie doładowania jest jednym ze sposobów na zwiększenie momentu obrotowego silnika. W literaturze [4, 14, 15, 18, 19, 22] znanych jest wiele układów doładowujących w sposób ciągły (np. układy sprężarkowe) względnie okresowy.

Interesującym rozwiązaniem jest układ przedstawiony $\mathrm{w}$ pracy [19], składający się z turbosprężarki oraz zasobnika ze sprężonym powietrzem. W chwili przyspieszania, gdy prędkość obrotowa sprężarki jest niewystarczająca, doprowadza się dodatkowe powietrze z zasobnika przez specjalny układ regulacji napływu powietrza do cylindra. W ten sposób uzupełnia się niedobór powietrza $\mathrm{w}$ cylindrze silnika, a w rezultacie otrzymuje się większy moment obrotowy i większą energię spalin, uzyskując szybsze rozpędzenie turbosprężarki. Maksymalna wydajność turbosprężarki osiągnięta została w tym przypadku o około 3,5 s wcześniej w porównaniu z tradycyjnym układem. Szybszy przyrost prędkości obrotowej turbosprężarki wpływa również korzystnie na moment obrotowy silnika.

W przypadku silników o zapłonie iskrowym problem jest bardziej założony z uwagi na zagrożenie spalaniem stukowym przy dużej ilości ładunku w cylindrze. To niekorzystne zjawisko można ograniczyć, obniżając temperaturę ładunku w wyniku gwałtownego rozprężenia powietrza $\mathrm{z}$ zasobnika. W pracy [14] przedstawiono koncepcję takiego układu krótkotrwałego doładowania i określono jego podstawowe parametry.

\section{Badania symulacyjne zjawisk w kolektorze dolotowym}

W celu poznania zjawisk występujących w układzie dolotowym opracowano jego model w pakiecie FLUENT służącym do symulowania zjawisk fizycznych i analizy przepływów. Obliczenia wykonywane za pomocą tego pakietu bazują na metodzie skończonych objętości $[1-3,6]$. Dokonano dyskretyzacji obszaru obliczeniowego, określono warunki brzegowe. Następnie badaniom poddano ustalony i dynamiczny stan czynnika w układzie dolotowym silnika.

Przeprowadzono symulacje przepływu powietrza $\mathrm{w}$ kolektorze dolotowym dla różnego uchylenia przepustnicy przy ustalonej prędkości obrotowej silnika. Badano zjawiska przepływowe podczas gwałtownego zwiększenia obciążenia silnika, tj. przy stałej prędkości obrotowej i zmiennym uchyleniu przepustnicy oraz zasymulowano działanie układu krótkotrwałego doładowania w kolektorze dolotowym [12, $14,16]$. Analizując wyniki symulacji, wyznaczono rozkłady prędkości strug powietrza oraz ciśnień panujących w kolektorze dolotowym, a uzyskane dane porównano z wartościami eksperymentalnymi. W pracy [6] opisano zastosowany model matematyczny, a poniżej przedstawiono wyniki dla wybranych stanów pracy.

Przepływ ustalony (quasi-statyczny) symulowano przy prędkości obrotowej silnika $n=1800 \mathrm{obr} / \mathrm{min}$ i stałym uchyleniu przepustnicy, następnie zadawano kolejny stopień uchylenia przepustnicy, uzyskując rozkłady kierunków i prędkości przepływu powietrza. Wyniki symulacji 
The simulation results were graphically presented in Fig.1 in the form of colored vectors, each color has an assigned appropriate velocity and flow direction. The velocity in the intake manifold increased along with the increasing throttle angle. At high velocities of the air stream flow through the volumetric part of the intake manifold the phenomenon of return flow occurs over the air intake tracts to each cylinder. This phenomenon occurs most intensively in the intake tract of cylinder four and is the result of the ejecting behavior of the flowing air stream at the intake stroke in cylinder 1 and 2. The highest flow velocities were recorded in intake tube 1 and 2, while in the other ones the flow velocities were on average by $0.5 \mathrm{~m} / \mathrm{s}$ lower.

a)

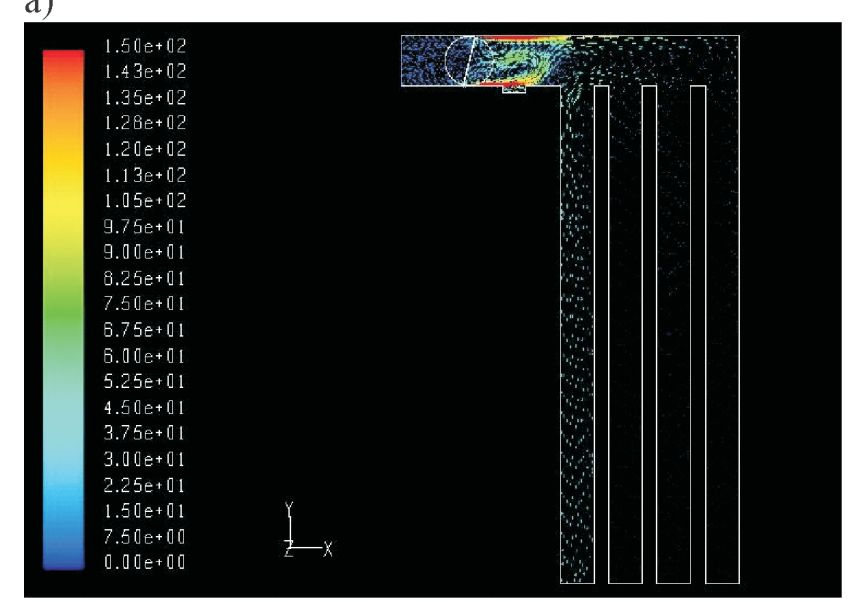

przedstawiono graficznie na rysunku $1 \mathrm{w}$ postaci barwnych wektorów, a każdemu z wybranych kolorów przypisana jest odpowiednia prędkość oraz kierunek przepływu. Wraz ze zwiększaniem uchylenia przepustnicy prędkość w kolektorze dolotowym wzrasta. Przy dużych prędkościach przepływu strugi powietrza przez część pojemnościową kolektora dolotowego dochodzi do zjawiska przepływu zwrotnego nad przewodami doprowadzającymi powietrze do poszczególnych cylindrów. Zjawisko to występuje najbardziej intensywnie w przewodzie dolotowym czwartego cylindra i wynika z eżektorowego działania strugi przepływającego powietrza przy suwie dolotu w 1 i 2 cylindrze. Największe prędkości przepływu zaobserwowano w 1 i 2 przewodzie b)

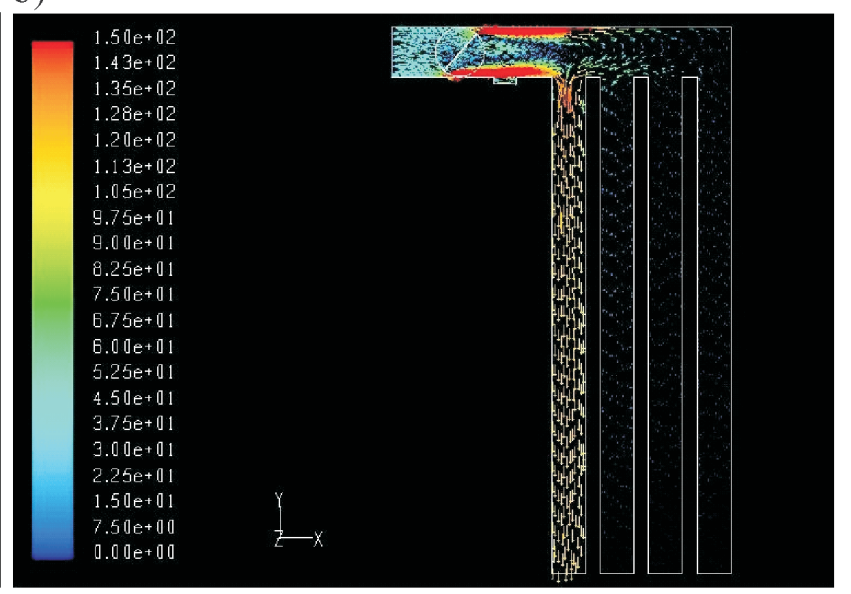

Fig. 1. Distribution of air flow velocity vectors and direction in the manifold for various throttle angles: a) $7 \%$ throttle angle, b) $37 \%$ throttle angle Rys. 1. Rozklad wektorów prędkości oraz kierunku przeplywu powietrza w kolektorze dla różnych uchyleń przepustnicy: a) 7\% uchylenia przepustnicy, b) $37 \%$ uchylenia przepustnicy

For throttle angles within the range from 7 to $16 \%$ distinct swirls occur in the throttling valve section and at throttle angles above $19 \%$ they flatten but do not disappear. Higher velocities were also recorded in the flow area between the

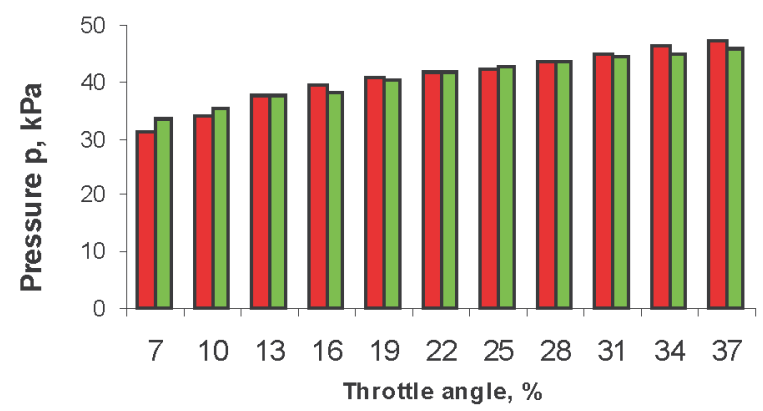

$\square$ Pressure obtained in simulation

$\square$ Pressure measured in the expeiment

Fig. 2. Comparison of the pressure values in the intake manifold determined as a result of computer simulation and those measured in the experiment, for different throttle angles

Rys. 2. Porównanie wartości ciśnienia w kolektorze dolotowym określo$n y c h w$ wyniku symulacji komputerowej oraz zmierzonych $w$ eksperymencie, dla różnego uchylenia przepustnicy dolotowym, podczas gdy w pozostałych prędkości przepływu były średnio o około $0,5 \mathrm{~m} / \mathrm{s}$ mniejsze.

Dla uchylenia przepustnicy w przedziale od 7 do $16 \%$ występują wyraźne wiry w części zespołu przepustnicy, które dla uchylenia powyżej 19\% ulegają spłaszczeniu, jednak nie zanikają. Zauważono również większe prędkości w obszarze przepływu pomiędzy zespołem przepustnicy a ścianką kolektora i jednocześnie mniejsze w osi poziomej przepływu, bezpośrednio przy przepustnicy. Prędkości te stopniowo zmniejszają się w dalszej części pojemnościowej kolektora nad poszczególnymi przewodami dolotowymi do cylindrów. Analizowano również rozkład ciśnienia panującego w kolektorze dolotowym dla różnego uchylenia przepustnicy, gdzie ciśnienie w układzie rośnie wraz z uchyleniem przepustnicy. Wyniki porównano z ciśnieniami zmierzonymi na rzeczywistym silniku i zestawiono na wykresie (rys. 2). Największa różnica ciśnienia wynosi $6 \%$, co odpowiada wartości $2 \mathrm{kPa}$.

Wyniki symulacji stanu dynamicznego w układzie $\mathrm{z}$ krótkotrwałym doładowaniem przedstawiono na rysunku 3. Zarówno przy 7-procentowym, jak i 37-procentowym uchyleniu przepustnicy można zauważyć wir tworzący się pomiędzy przepustnicą a kanałem doprowadzającym powietrze doładowujące z wysokociśnieniowego zasobnika. Wynika 
throttling valve and the intake manifold wall and at the same time lower velocities - in the horizontal axis of the flow, directly near the throttling valve. The velocities decrease gradually in the further volumetric part of the intake manifold

a)

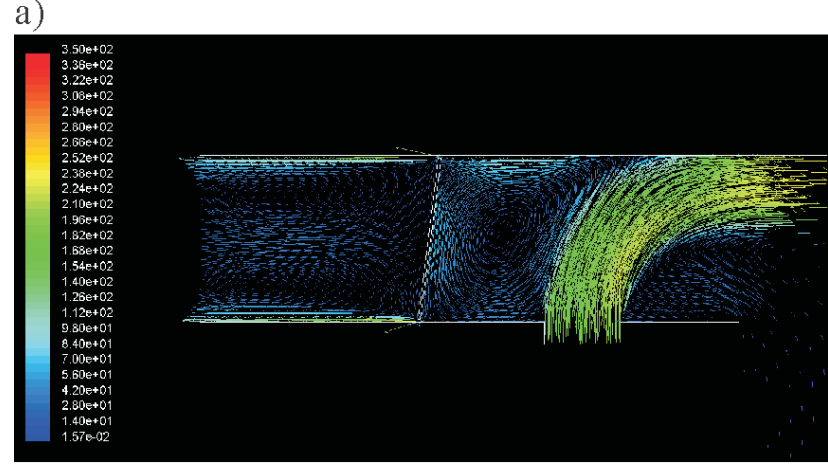

to z większego strumienia masy powietrza przepływającego przez ten obszar. W obu przypadkach widać przepływ w kierunku przepustnicy, co wynika z tego, iż ciśnienie w kolektorze dolotowym jest wyższe niż przed przepustnicą.

b)

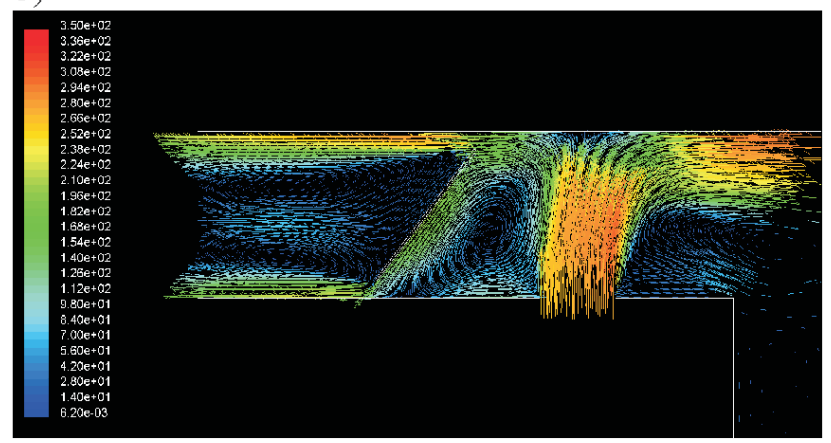

Fig. 3. Distribution of velocity vectors and air flow with engine supercharge: a) $7 \%$ throttling valve opening angle, b) $37 \%$ throttling valve opening angle

Rys. 3. Rozkład wektorów prędkości oraz kierunku przepływu powietrza przy doładowaniu silnika: a) 7\% uchylenia przepustnicy, b) $37 \%$ uchylenia przepustnicy

over the specific cylinder air intake tracts for various throttle angles where the pressure in the system grows along with the throttle angle. The results were compared to the pressures measured on the real engine and listed on the diagram (Fig. 2). The largest pressure difference is $6 \%$, which corresponds to $2 \mathrm{kPa}$.

The simulation results for the dynamic state in the system with short-time supercharging were presented in Fig. 3. For both $7 \%$ and $37 \%$ throttle angles, the swirls occurring between the throttling valve and the air tract supplying the charging air from the high-pressure accumulator can be seen. This is a result of higher weight of the stream flowing through this area. In both cases the flow towards the throttling valve is visible, which results from the fact that the pressure in the intake manifold is higher than that before the throttling valve. Part of the charging air leaves the manifold through this way, which reduces the pressure in the manifold below the nominal charging pressure.

At the dynamic state, the air flow in the intake manifold was examined upon abrupt opening of the throttling valve with angular velocity of 300 degrees/s. After the desired $37 \%$ throttle angle has been obtained, the short-time air supercharging takes place at absolute pressure of $300 \mathrm{kPa}$ for the duration of 12 cycles as presented in Fig. 4 . The charging air causes the growth of the air stream velocity after the throttling valve. Then, after ca. $0.03 \mathrm{~s}$ from the beginning of the charging period, the flow velocity decreases and the pressure in the intake channels grows. At the same time the air flow towards the ambient air intake direction, causing the charging pressure reduction to ca. $200 \mathrm{kPa}$. The charging air stream results in a high swirl in the area over the intake tract of cylinder 4 and the ejecting behavior of the stream causes the flow direction change in this tract. The air is returned to the volumetric part of the intake manifold and the pressure in the channel is reduced
Część powietrza doładowującego silnik opuszcza kolektor tą drogą, co obniża ciśnienie w kolektorze poniżej nominalnego ciśnienia doładowania.

W stanie dynamicznym zbadano również przepływ powietrza w kolektorze dolotowym po gwałtownym uchyleniu przepustnicy z prędkością kątową wynoszącą 300 stopni/s. Po uzyskaniu żądanego 37-procentowego uchylenia przepustnicy następuje doładowanie krótkookresowe powietrzem o ciśnieniu bezwzględnym $300 \mathrm{kPa}$ na czas trwania 12 cykli, co przedstawiono na rysunku 4. Powietrze doładowujące wywołuje wzrost prędkości strugi powietrza za przepustnicą. Następnie, po ok. 0,03 s od początku procesu doładowania, prędkość przepływu maleje i następuje zwiększenie ciśnienia w kanałach dolotowych. Jednocześnie w obszarze przepustnicy pojawia się zjawisko przepływu powietrza w kierunku wlotu powietrza atmosferycznego, co powoduje obniżenie ciśnienia doładowania do ok. $200 \mathrm{kPa}$. Przepływ strumienia powietrza doładowującego skutkuje dużym zawirowaniem w obszarze nad przewodem dolotowym 4 cylindra, a eżektorowe działanie strugi wywołuje zmianę kierunku przepływu w tym kanale. Powietrze zostaje cofnięte do części pojemnościowej kolektora, a ciśnienie w kanale obniża się do ok. $40 \mathrm{kPa}$ (po $0,0044 \mathrm{~s}$ od początku procesu doładowania). Po 0,0176 s od początku doładowania ciśnienie w tym kolektorze dolotowym zaczyna wzrastać, a po 0,028 s wyrównuje się $\mathrm{z}$ ciśnieniem panującym w pozostałej części kolektora.

Przedstawione rozkłady ciśnienia w kolektorze dolotowym dla kolejnych kroków czasowych (rys. 4b) wskazują na zjawisko pulsowania ciśnienia występujące zarówno w procesie bez doładowania, jak i w procesie z doładowaniem. Wahania ciśnienia wynoszą do ok. 20 $\mathrm{kPa} \mathrm{w}$ procesie bez doładowania, a w procesie $\mathrm{z}$ doładowaniem $40 \mathrm{kPa}$.

Porównując przepływ w układzie dolotowym silnika bez i z doładowaniem, można stwierdzić, że przy przepływie 
a)

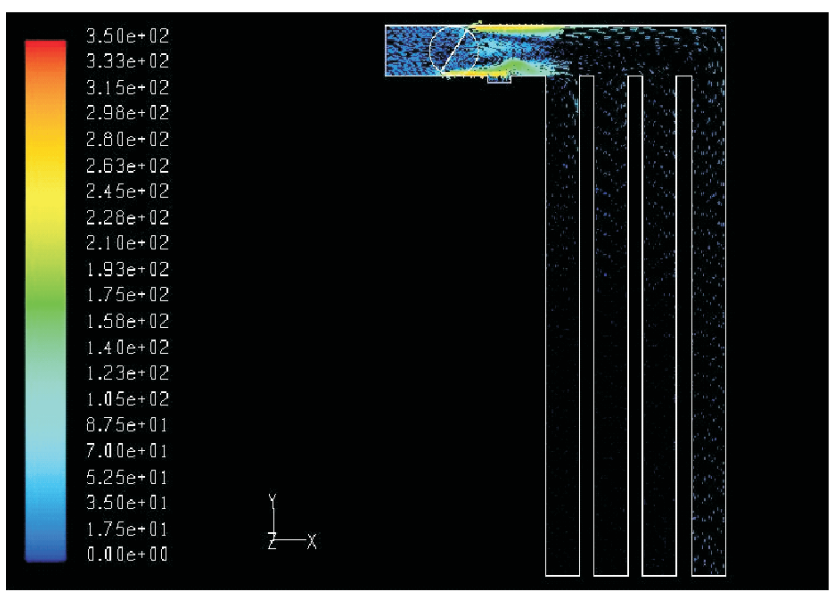

Supercharging beginning b)

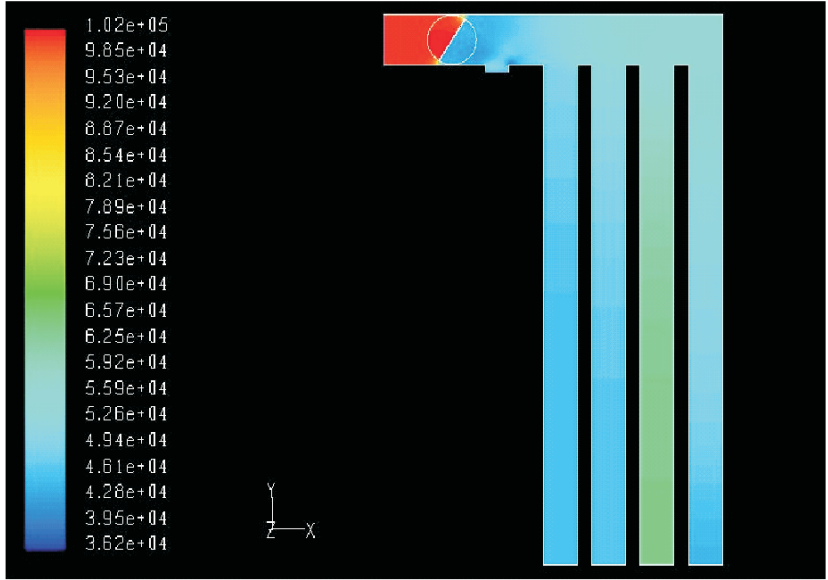

Supercharging beginning

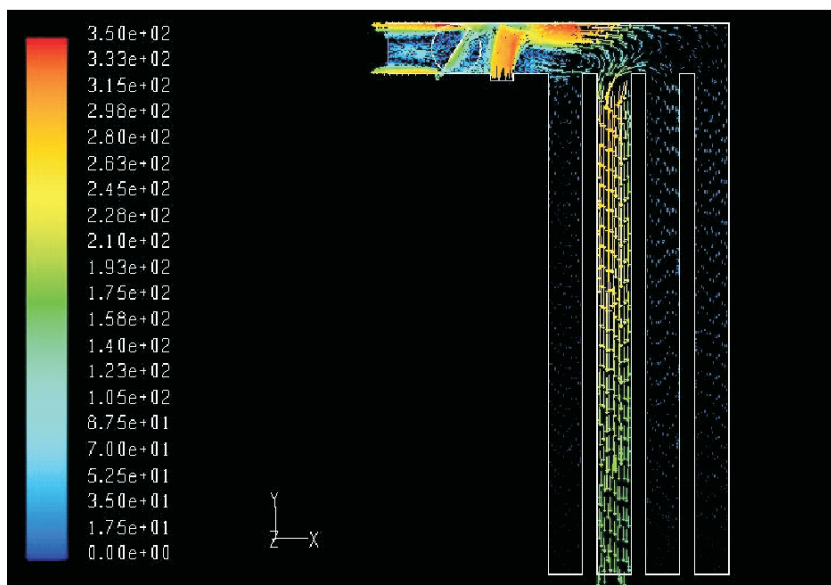

after $0.0204 \mathrm{~s}$

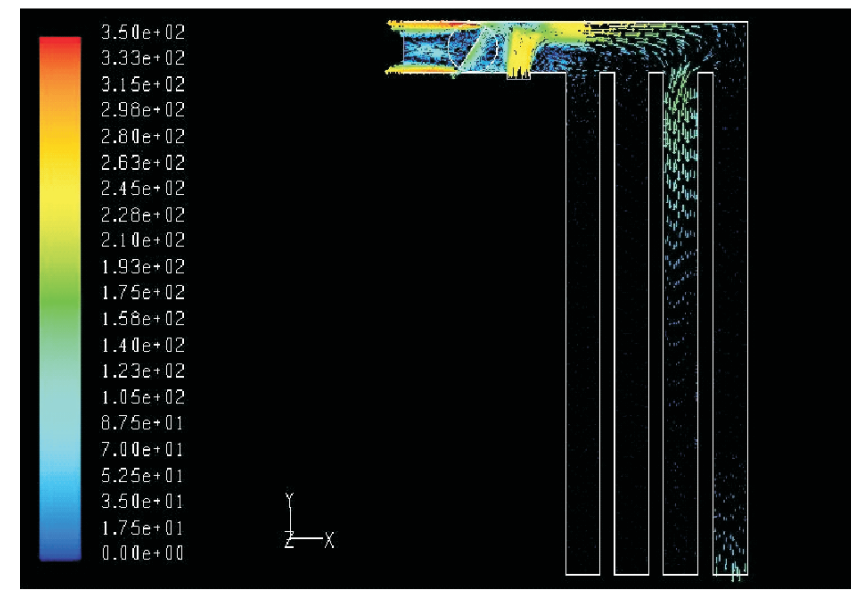

after $0.0668 \mathrm{~s}$

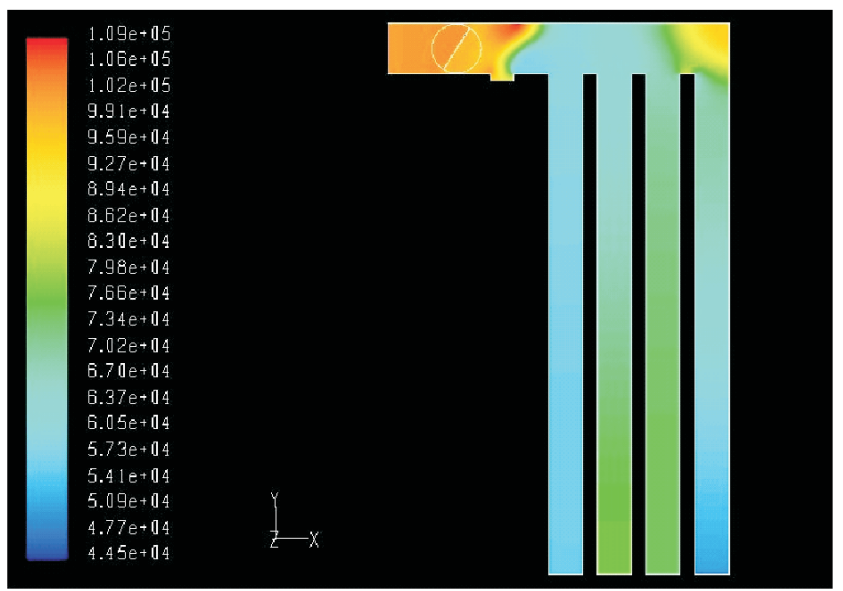

after 0.028

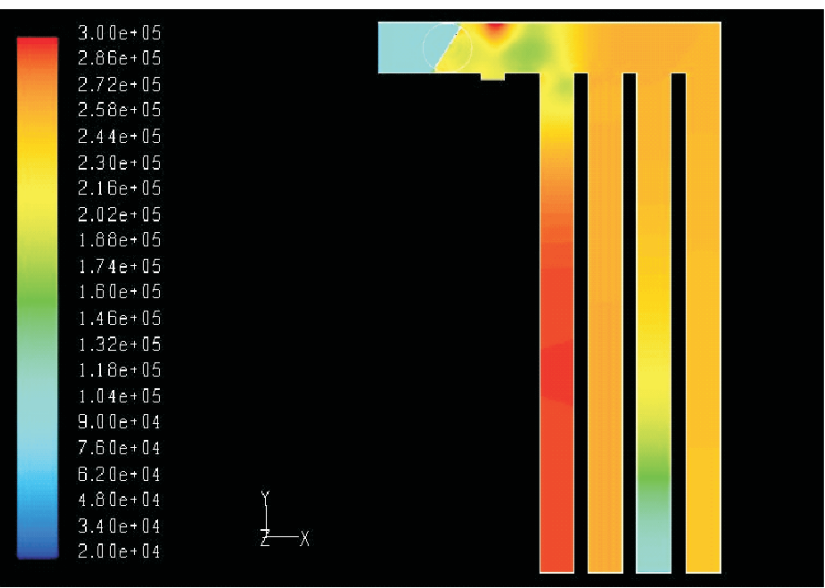

after $0.0504 \mathrm{~s}$

Fig. 4. The course of supercharging in the intake manifold at subsequent time steps: a) air velocity and flow direction vectors distribution in the supercharging process, $b$ ) pressure changes for the supercharging process

Rys. 4. Przebieg procesu doładowania w kolektorze w kolejnych krokach czasowych: a) rozkład wektorów prędkości oraz kierunku przeplywu powie-

trza w procesie doładowania, b) zmiany ciśnienia dla procesu doladowania

to ca. $40 \mathrm{kPa}$ (after $0.0044 \mathrm{~s}$ from the onset of supercharging). After $0.0176 \mathrm{~s}$ from the onset of supercharging, the pressure in this intake manifold begins to grow and after $0,028 \mathrm{~s}$ it becomes equal to the pressure of the remaining part of the intake manifold. z doładowaniem średnia prędkość przepływu w kanałach dolotowych nad zamkniętymi zaworami osiąga wartości od 50 do $70 \mathrm{~m} / \mathrm{s}$, natomiast ciśnienie zmienia się ok. 120 do $180 \mathrm{kPa}$. Dla przepływu bez doładowania prędkość ta jest znacznie mniejsza i zmienia się z ok. 5 do $15 \mathrm{~m} / \mathrm{s}$, a 
The pressure distributions presented for the intake manifold for subsequent time-steps (Fig. 4b) indicate the pulsating pressure phenomenon occurring both in the processes with and without supercharging. The pressure fluctuations are up to ca. $20 \mathrm{kPa}$ in the process without supercharging, and 40 $\mathrm{kPa}$ with supercharging.

Comparing the flow in the intake systems of engine with and without supercharging, we may find that the mean flow velocity in the intake channels over the valves closed is 50 do $70 \mathrm{~m} / \mathrm{s}$, while the pressure changes by ca. 120 to $180 \mathrm{kPa}$ for the flow with supercharging. For the unsupercharged flow the velocity is significantly lower and varies between 5 and $15 \mathrm{~m} / \mathrm{s}$ with the pressure within the range from 50 to $70 \mathrm{kPa}$. The numerical tests carried out enabled a development of an image of the supercharging process and select the most efficient option for the real engine. The location of the supercharging air intake past the throttling valve was found appropriate provided that the appropriate throttle angle is maintained so that the throttle angle would be $7 \%$ during the supercharging process, in order to restrict the phenomenon of supercharging air flow towards the intake manifold inlet, which means a reduction in the supercharging pressure. Moreover, the simulation tests proved that the location of the pressure sensor directly past the throttling valve is unfavorable due to high swirls of the stream occurring in this area. The placement of the OEM pressure sensor in the flow stagnation zone makes its indications more neutral.

\section{Engine test stand investigations}

The engine whose parameters were used in the simulation model (188A.5000 engine of Fiat Punto II Speed Gear) was used in the tests. Relevant modifications of the fuelling system, described in paper [15] were made in the engine. The engine was fitted with a short-time supercharging system consisting of a compressed-air accumulator, a set of reducers with electromagnetic injectors and an ECU. The analysis of the engine power increase potential through the increase of cylinder filling coefficient as a result of an application of a short-time accumulative supercharging was carried out based ciśnienie w zakresie od 50 do $70 \mathrm{kPa}$. Przeprowadzone badania numeryczne pozwoliły na zobrazowanie procesu doładowania i wybranie opcji najbardziej efektywnej w rzeczywistym silniku. Ustalono, iż ulokowanie wlotu powietrza doładowującego za przepustnicą jest słuszne przy zachowaniu odpowiedniego uchylenia przepustnicy, tak aby w trakcie procesu doładowania przepustnica była przymknięta 7\%, w celu ograniczenia zjawiska przepływu powietrza doładowującego w kierunku wlotu kolektora dolotowego, a tym samym obniżania się ciśnienia doładowania. Ponadto badania symulacyjne wykazały, że umiejscowienie czujnika ciśnienia bezpośrednio za przepustnicą jest niekorzystne, ze względu na duże zawirowania strugi występujące w tym rejonie. Umiejscowienie fabrycznego czujnika ciśnienia w strefie stagnacji przepływu sprawia, że jego wskazania są bardziej obiektywne.

\section{Badania stanowiskowe}

Do badań zastosowano silnik, którego parametry wykorzystano w modelu symulacyjnym (silnik 188A.5000 z samochodu Fiat Punto II Speed Gear). W silniku przeprowadzono stosowane modyfikacje układu zasilania, opisane w pracy [15], wyposażając go w układ krótkotrwałego doładowania, na który składają się zasobnik sprężonego powietrza, zespół reduktorów z elektromagnetycznym wtryskiwaczem oraz ECU układu. Analizę możliwości zwiększenia mocy silnika przez zwiększenie współczynnika napełnienia cylindrów w wyniku zastosowania krótkotrwałego doładowania zasobnikowego przeprowadzono w oparciu o pomiary ciśnienia wewnątrz cylindra w silniku testowym dla charakterystyki zewnętrznej. Obserwacja ciśnienia wewnątrz cylindra, jak wykazano w pracy [13], przekłada się na uzyskany moment obrotowy silnika. Analizowano również przebieg ciśnienia pod kątem niebezpieczeństwa wystąpienia spalania stukowego dla charakterystyki zewnętrznej silnika przy 1500 , 2500, 3500, 4500, 5500 obr/min. Z rysunków 5a i b wynika, iż spalanie stukowe nie występowało.

Warto zwrócić uwagę (rys. 5) na opóźnienie zapłonu, które zapobiega spalaniu stukowemu, zwłaszcza przy ma- a)

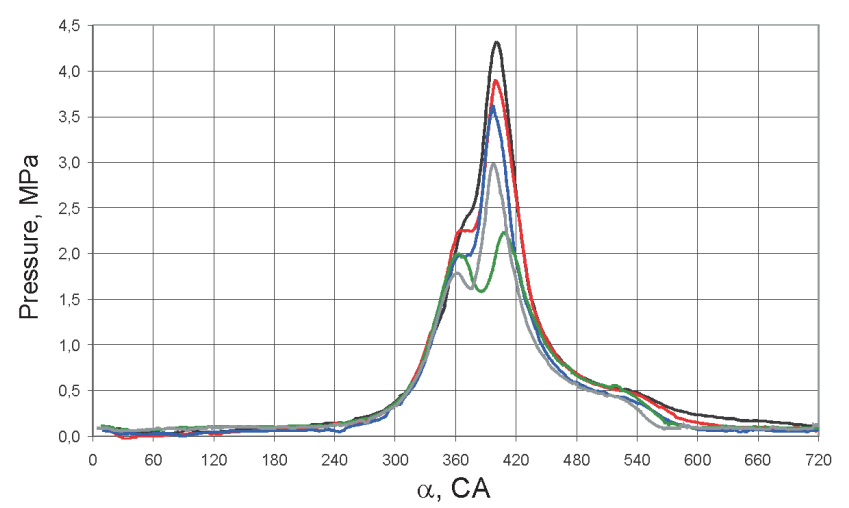

b)

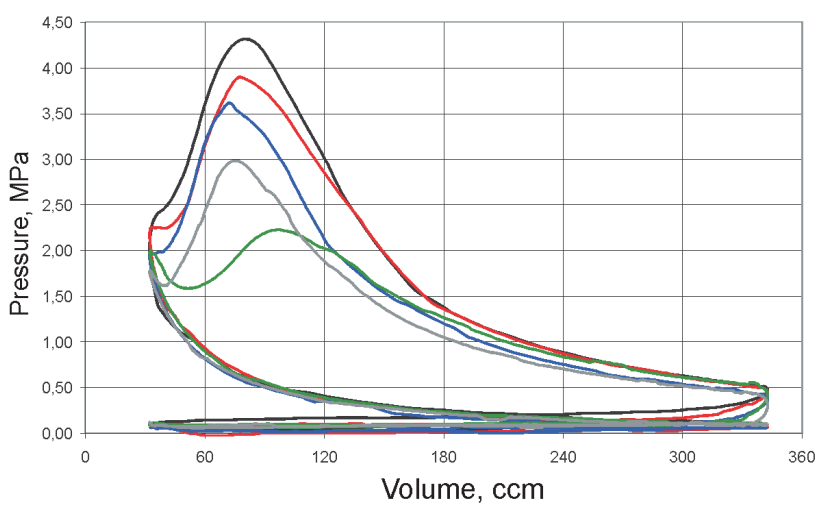

Fig. 5. Indicator diagram for full throttling valve opening: a) open, b) closed (black line $5500 \mathrm{rpm}$, red line $4500 \mathrm{rpm}$, blue line $3500 \mathrm{rpm}$, green line $2500 \mathrm{rpm}$, grey line $1500 \mathrm{rpm})$

Rys. 5. Wykres indykatorowy dla petnego otwarcia uchylenia przepustnicy: a) otwarty, b) zamknięty (linia czarna 5500 obr/min, linia czerwona 4500 obr/min, linia niebieska $3500 \mathrm{obr} / \mathrm{min}$, linia zielona $2500 \mathrm{obr} / \mathrm{min}$, linia szara $1500 \mathrm{obr} / \mathrm{min}$ ) 
on the pressure measurements inside the cylinder of the test engine for the external characteristics. Monitoring the pressure inside the cylinder in the test engine is translated into the engine torque, as proven in paper [13]. The pressure course (in terms of the risk of occurrence of knocking combustion) for the engine external characteristics at engine speeds 1500 , 2500, 3500, 4500, $5500 \mathrm{rpm}$ was also analyzed. Fig. 5a and $5 \mathrm{~b}$ indicate that no knocking combustion occurred.

a)

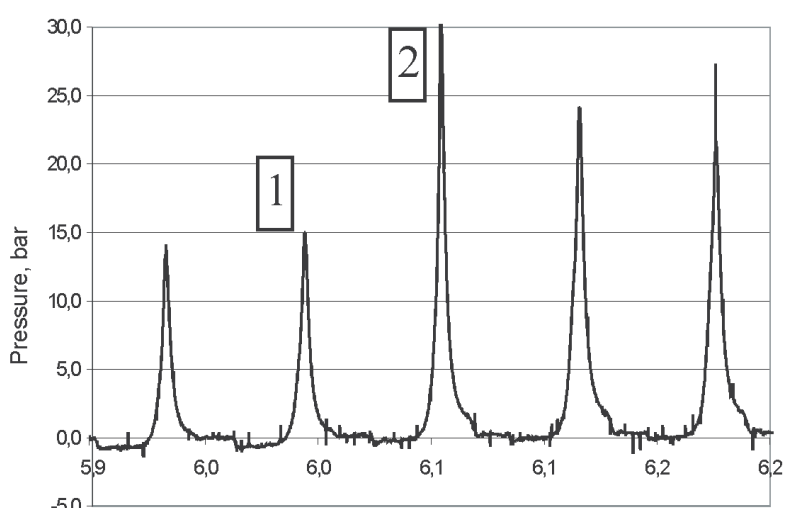

Time, $s$ łej prędkości obrotowej silnika. Z badań symulacyjnych opisanych w poprzednim rozdziale wynika, że najbardziej skuteczne jest doładowanie przy przymkniętej przepustnicy (uchylenie równe 7\%). Dla takich warunków przeprowadzono badania stanowiskowe silnika doładowanego.

$\mathrm{Na}$ rysunku 6 przedstawiano czasowy przebieg zmian ciśnienia wewnątrz cylindra oraz wykres indykatorowy dla dwu kolejno następujących po sobie cykli, dla silnika doła-

b)

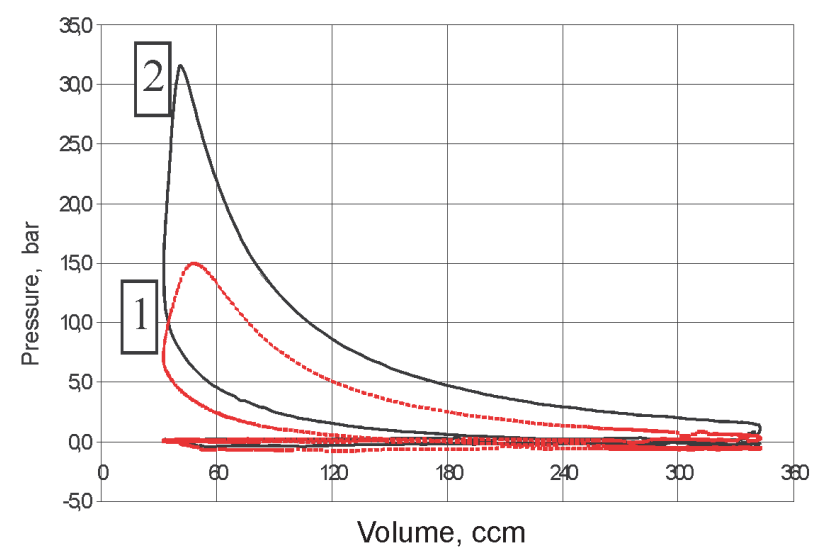

Fig. 6. Indicator diagrams for short-time supercharging: a) open, b) closed (red line - before supercharging, black line - after supercharging) Rys. 6. Wykresy indykatorowe dla krótkotrwałego doładowania: a) otwarty, b) zamknięty (linia czerwona-przed doładowaniem, linia czarna - po doładowaniu)

The ignition delay (Fig. 5) is worth noticing as it prevents knocking combustion, especially at low engine speeds. The simulation tests described in the previous chapter indicate that supercharging with the throttling valve not fully closed is most efficient ( $7 \%$ throttle angle). The engine test stand investigation of the supercharged engine was carried out under the above conditions.

Figure 6 presents the time course of the pressure changes inside the cylinder and an indicator diagram for two subsequent cycles, for engine supercharged at effective supercharging pressure $155 \mathrm{kPa}$ and $1800 \mathrm{rpm}$ engine speed. The fuel dose was increased simultaneously to an increase in the supercharging. The supercharging process under the above conditions gave a positive effect on the course of the changes inside the cylinder (Fig. 6) and the temperature in the intake manifold dropped, which was presented in Fig. 7. The temperatures were measured by a specially designed set of three thermocouples - type K by OMEGA - that enabled measuring with the frequency of $250 \mathrm{~Hz}$. The first thermocouple was mounted before the throttling valve, the second one in the intake manifold and the third one after the air injector at the inlet of the decompressed air into the manifold. The air temperature in the volumetric part of the intake manifold dropped by ca. $10^{\circ} \mathrm{C}$ during the supercharging process. Simultaneously, no temperature change before the throttling valve was recorded. In this case no return air flow from the volumetric part of the intake manifold towards the ambient air filter occurs and the whole air charged from dowanego przy ciśnieniu efektywnym doładowania $155 \mathrm{kPa}$ i prędkości obrotowej silnika 1800 obr/min. Równocześnie z doładowaniem zwiększono dawkę paliwa. Realizacja procesu doładowania w takich warunkach korzystnie wpłynęła na przebieg zmian ciśnienia wewnątrz cylindra (rys. 6) oraz odnotowano spadek temperatury w kolektorze dolotowym, co zostało przedstawione na rysunku 7. Do pomiaru temperatur użyto specjalnie zaprojektowanego układu trzech termopar typu K firmy OMEGA, które umożliwiały pomiar z częstotliwością $250 \mathrm{~Hz}$. Pierwszą termoparę zamontowano przed przepustnicą, drugą w kolektorze dolotowym, a trze-

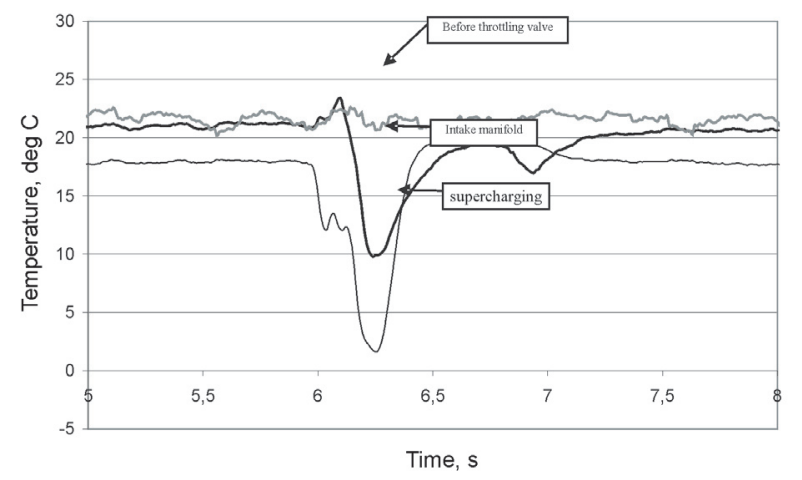

Fig. 7. Course of temperature changes in the intake manifold for shorttime supercharging

Rys. 7. Przebieg zmian temperatury w kolektorze dolotowym dla krótkotrwatego doładowania 
a)

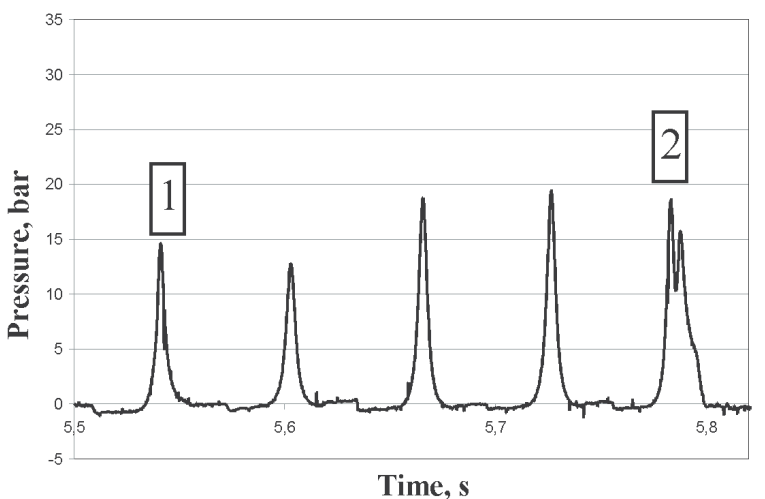

b)

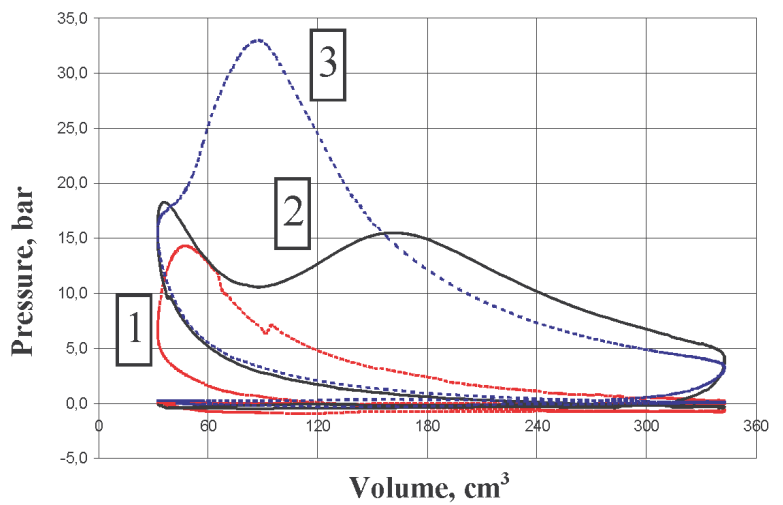

Fig. 8. Indicator diagrams for slight throttling valve opening: a) open b) closed (red line (1) - initial, black line (2) - transitional, dotted line (3) - with the throttling valve wide open)

Rys. 8. Wykresy indykatorowe dla naglego uchylenia przepustnicy: a) otwarty, b) zamknięty (linia czerwona (1) - wyjściowy, linia czarna (2) - przejściowy, linia przerywana (3) - przy pelnym otwarciu przepustnicy)

the accumulator is supplied to individual cylinders. Thus, the assumption of the simulation tests concerning the necessity of supercharging with the throttling valve not fully closed, proves to be right.

The pressure inside the cylinder was also analyzed after abrupt opening of the throttling valve up to the maximum value, at the engine speed of $1800 \mathrm{rpm}$ for an unsupercharged engine (Fig. 8). In this case the pressure growth is lower and delayed in time. For the cycle marked as No. 2 in drawing 8 , the excessive ignition delay is visible, which prevents the knocking combustion. The maximum pressure marked as No. 3, was reached after $0.8 \mathrm{~s}$ only from the throttling valve opening time, and the maximum pressure during the transition process is by 10 bar lower than that of the supercharged engine.

The consequence of a different pressure course inside the cylinder is the course of torque in time (Fig. 9). It is conspicuous that a $50 \%$ growth of the torque value was achieved as a result of supercharging with the accretion time growing from 0.8 to $0.2 \mathrm{~s}$.

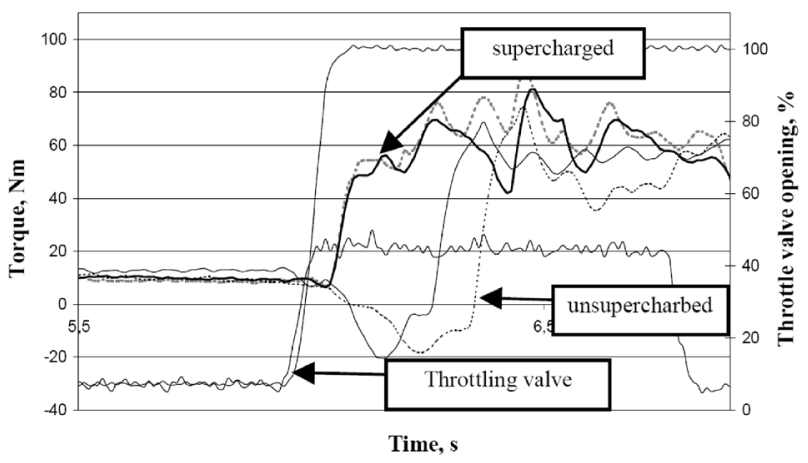

Fig. 9. Comparison of torque in time for a supercharged and an unsupercharged engine

Rys. 9. Porównanie przebiegu momentu obrotowego $w$ czasie dla silnika doładowanego $i$ wolnossacego cią za wtryskiwaczem powietrza przy wlocie rozprężonego powietrza do kolektora. Temperatura powietrza w części pojemnościowej kolektora podczas doładowania obniżyła się o około $10^{\circ} \mathrm{C}$, jednocześnie nie odnotowano zmiany temperatury przed przepustnicą. W tym przypadku nie dochodzi do zjawiska przepływu zwrotnego powietrza $\mathrm{z}$ części pojemnościowej kolektora w kierunku filtra powietrza atmosferycznego, a całe powietrze doładowywane $\mathrm{z}$ zasobnika jest dostarczane do poszczególnych cylindrów. Potwierdza to słuszność przyjętego założenia z badań symulacyjnych o konieczności prowadzenia procesu doładowania z przymkniętą przepustnicą.

Analizie poddano także przebieg zmian ciśnienia wewnątrz cylindra, po gwałtownym uchyleniu przepustnicy do wartości maksymalnej, przy prędkości 1800 obr/min dla silnika wolnossącego (rys. 8). W tym przypadku przyrost ciśnienia jest mniejszy i opóźniony w czasie. Dla cyklu oznaczonego na rysunku 8 numerem 2 widoczne jest nadmierne opóźnienie zapłonu, które zapobiega spalaniu stukowemu. Maksymalne ciśnienie, oznaczone numerem 3, osiągnięto dopiero po $0,8 \mathrm{~s}$ od chwili otwarcia przepustnicy, a ciśnienie maksymalne w procesie przejściowym jest o 10 barów mniejsze niż w silniku doładowanym.

Konsekwencją odmiennego przebiegu ciśnienia wewnątrz cylindra jest czasowy przebieg momentu obrotowego silnika (rys. 9). Jak widać, na skutek doładowania uzyskano 50-procentowy przyrost wartości momentu obrotowego przy skróceniu czasu narastania z 0,8 do $0,2 \mathrm{~s}$.

\section{Podsumowanie}

Przedstawiony w pracy układ krótkotrwałego doładowania zasobnikowego korzystnie wpływa na wskaźniki pracy silnika w procesie przejściowym, wynikającym z potrzeby szybkiego zwiększenia jego mocy. Badania wykonane techniką symulacji cyfrowej pozwoliły na poznanie przepływu ładunku przez kolektor. Osiągnięto przy tym dużą zgodność wyników symulacji z wartościami eksperymentalnymi. Jednocześnie wykazano, że obniżenie temperatury powietrza w 


\section{Summary}

The short-time accumulative supercharging system presented in this paper positively influences the engine operation indexes in the transient process, resulting from the need for fast engine power increase. The tests carried out with the use of a digital simulation technique enabled the authors to examine the charge flow through the intake manifold. At the same time high convergence of the simulation results with the experimental values was achieved. It was also proven that the temperature reduction in the intake manifold achieved through abrupt accumulative air decompression prevents a knocking combustion, which allows an increase in the ignition angle and an improved pressure in the cylinder. As a consequence, significant growth of torque was achieved and along with dynamic engine properties.

Paper reviewed

\section{Bibliography/Literatura}

[1] Fluid Dynamics Analysis Package. Fluid Dynamics International, Inc. 2007.

[2] Ferziger J.H., Perić M.: Computational Methods for Fluid Dynamics, Springer-Verlag, Berlin Heidelberg 1999.

[3] Abida J., Clalide D.: Spark ignition engines and pollution emission. New approaches in modelling and control. International Journal of Vehicle Design, Vol. 15, 1994, pp. 494-509.

[4] Bernhard M., Dobrzyński S., Lothe E.: Silniki samochodowe, WKiŁ, Warszawa.

[5] Che-Wun Hong: A fuzzy throttle controller for dynamic driving pattern simulation, International Journal of Vehicle Design, Vol. 16, 1995, pp. 203-218.

[6] Dobrowolski B., Jantos J., Lenc-Brol A.: Badania symulacyjne zjawisk w kolektorze dolotowym silnika spalinowego w czasie krótkookresowego doładowania zasobnikowego. Silniki Spalinowe, Opole 2009, PTNSS-2009-SC-011.

[7] Cichy M.: Pomiar momentu bezwładności i oporów mechanicznych metodą wybiegu, Technika Motoryzacyjna nr 1, 1969.

[8] Gervas K., Pronin B.: Calculation of power losses in belt drivers. Russian Engineering Journal, Vol. 47, No. 3, pp. 26-29, 1967.

[9] Ide T.: Effect of Power Losses of Metal V-Belt CVT Components on the Fuel Economy. International Congress on Continuously Variable Power Transmission CVT'99, Eindhoven University of Technology, Eindhoven 1999, pp. 93-98.

[10] Jantos J., Korniak J., Mamala J., Siłka W.: Driveability and fuel consumption improvement through integrated fuzzy logic control of powertrain with spark ignition engine and continuously variable transmission, FISITA World Automotive Congress, Barcelona, No. F2004F414.

[11] Jantos J., Mamala J.: Badania algorytmów działania nadzorczego sterownika napędu w aspekcie ekologicznym. Teka Komisji Naukowo-Problemowej Motoryzacji PAN, ISSN 1642-1639, Kraków 2001, z. 22, s. 200-204.

[12] Jantos J., Mamala J.: Zintegrowany system sterowania napędu samochodu osobowego. Zeszyty Naukowe Politechniki Opolskiej, seria Mechanika, z. 56, nr 241, 1998, s. 33-46.

[13] Jantos J., Mamala J.: Zużycie paliwa podczas ruchu samochodu ze zmienną prędkością. Konstrukcja, badania, eksploatacja, technologia pojazdów samochodowych i silników spalino- kolektorze, osiągnięte przez raptowne rozprężenie powietrza z zasobnika, zapobiega spalaniu stukowemu, co pozwala na zwiększenie kąta wyprzedzenia zapłonu i poprawę przebiegu ciśnienia w cylindrze. W rezultacie osiągnięto znaczący przyrost momentu obrotowego i polepszono właściwości dynamiczne silnika.

\section{Nomenclature/Skróty i oznaczenia}

t time/czas, s

$\mathrm{J}_{\mathrm{s}} \quad$ engine polar moment of inertia/biegunowy moment bezwładności silnika, $\mathrm{kg} \cdot \mathrm{m}^{2}$

$\mathrm{M}_{\mathrm{o}} \quad$ torque/moment obrotowy silnika, $\mathrm{N} \cdot \mathrm{m}$

$\Delta \mathrm{M}_{\mathrm{o}} \quad$ torque growth/przyrost momentu obrotowego silnika, $\mathrm{N} \cdot \mathrm{m}$

$\mathrm{M}_{\mathrm{zw}}{ }^{\circ} \quad$ torque for $100 \%$ load/moment obrotowy silnika dla $100 \%$ obciążenia, $\mathrm{N} \cdot \mathrm{m}$

$\omega_{\mathrm{s}} \quad$ crankshaft angular velocity/prędkość kątowa watu korbowego, $\mathrm{rad} \cdot \mathrm{s}^{-1}$

$\Delta \omega_{\mathrm{s}} \quad$ crankshaft angular velocity growth/przyrost prędkości katowej watu korbowego, $\mathrm{rad} \cdot \mathrm{s}^{-1}$

$\Delta \mathrm{N}_{\mathrm{e}} \quad$ power output growth/przyrost mocy użytecznej, $\mathrm{kW}$

ECU electronic control unit - microchip controller of accumulative supercharging system/sterownik mikroprocesorowy układu doładowania zasobnikowego

wych, PAN oddział w Krakowie, Teka Komisji NaukowoProblemowej Motoryzacji, Kraków 1999, z. 18, s. 121-126.

[14] Mamala J., Jantos J., Bieniek A., Brol S.: Compensation of mechanical inertia in passenger car with spark ignition engine, EAEC 2007, 11th European Automotive Congress, Budapest 2007, s. 8.

[15] Mamala J., Jantos J., Brol S., Malewicz K., Bieniek A.: The system of supercharging for the spark-ignition engine, Journal of Kones, vol. 14, no. 2, 2007, s. 291-298.

[16] Mamala J., Jerzy J., Bieniek A., Brol S.: The Powertrain Mechanical Inertia of a Passenger car in the process of Accejerating, International Congress Motor Vehicles \& Motors 2008.

[17] Merkisz J.: Ekologiczne problemy silników spalinowych, t.1, Wydawnictwo Politechniki Poznańskiej, Poznań 1998.

[18] Mysłowski J.: Doładowanie bezsprężarkowe silników z zapłonem samoczynnym, WNT, Warszawa.

[19] Nemeth H., Filer P., Palkovics L.: Diesel engine response improvement by compressed air charging, EAEC 200711 th Europen Automotive Congres, Budapeszt 2007, s. 13.

[20] Vroemen B., Veldpaus F.: Hydraulic circuit design for CVT control. International Congress on Continuously Variable Power transmission CVT'99, Eindhoven University of Technology, Eindhoven 1999, pp. 11-111.

[21] Wendeker M.: Opis zjawisk dynamicznych w procesie tworzenia mieszanki paliwowo-powietrznej w silnikach z wtryskiem benzyny, Zeszyty Naukowe Politechniki Łódzkiej, filia w Bielsku-Białej, Budowa i Eksploatacja Maszyn, z. 22, s. 45-57.

[22] Wislocki K.: Systemy doładowania szybkoobrotowych silników spalinowych, WKiŁ, Warszawa.

Mr. Jarosław Mamala, DEng. - doctor at the Faculty of Mechanical Engineering of Opole University of Technology.

Dr inż. Jarosław Mamala - adiunkt na Wydziale Mechanicznym Politechniki Opolskiej e-mail: j.mamala@po.opole.pl 